\title{
An investigation on different factors influencing growth of banking deposits
}

\author{
Sudabeh Morshedian Rafiee ${ }^{\mathrm{a}^{*}}$ and Zahra Houshmand Neghabi ${ }^{\mathrm{b}}$
}

${ }^{a}$ Assist. Prof. \& Faculty Member, Department of Commercial Management, Islamshahr Branch, Islamic Azad University (IAU), Tehran, Iran ${ }^{b}$ Faculty member, Department of Commercial Management, Islamshahr Branch, Islamic Azad University (IAU), Iran

\section{H R O N I C LE A B T R A C T}

Article history:

Received June 21, 2012

Received in revised format

30 October 2012

Accepted 8 November 2012

Available online

November 102012

Keywords:

Capital Market

Foreign Exchange

Commodity Market

Money Market

Banking Deposit

\begin{abstract}
Banking deposit is the primary source of contributing to economy and it is important to understand what factors influence such deposits. In this paper, we present an empirical study to find the relationship between banking deposit and other important factors such as capital market, money market, commodity market, foreign exchange rates such as US dollar and Euro exchange rates to local currency (Rials). We gather the data over the period of 2010-2012 and using ordinary least square technique study different hypotheses. All t-student values are statistically meaningful when the level of significance is ten percent and some of the parameters are even meaningful when the level of significance is five percent. The results indicate that the rate of bank deposit is negatively associated with commodity market growth rate (-.001995), US dollar exchange rate $(-0.004167)$, banking industry growth rate $(-0.278826)$ and moving average (-0.940418). In addition, dependent variable is positively associated with Euro exchange growth rate $(0.005676)$.
\end{abstract}

\section{Introduction}

During the past few years, there have been many changes on financial economies in the world. We have witness that many well-known North American banks filed bankruptcy for many reasons. When Leman Brothers announced bankruptcy protection news, many people around the world were in terrible shock since there were in business for 159 years and no one expected to see their unhappy end. The chaos was soon spread to European countries and the bad consequences influenced all countries around the world. When banking industry faces challenges, other business activities are also confronted with serious problems. They cannot finance their business activities through getting loans from banks and their production and services are interrupted. There are literally many different studies to investigate the effect of various parameters on banking industry.

*Corresponding author. Tel: +98-912-3443139

E-mail addresses: morshedian_rafiee@yahoo.com (S. Morshedian Rafiee) 
Beikzad and Ghorbannejad Maleki (2012) investigated effective factors on bank resource mobilization and concluded that information and communication technology, service diversity, human resource skills, internal environment utility and locations are among the most influencing on resource mobilization. Karami et al. (2012) presented a hybrid of balanced score card (BSC) and data envelopment analysis (DEA) method for measuring the performance of banking sector. The study determined various important factors associated with each four perspectives of BSC and implemented analytical hierarchy process to rank the measures. Khodaei Valahzaghard et al. (2012) investigated the impact of macroeconomic factors on credit risk in the banking system of Iran and reported no significant relationship between the inflation rate, employment rate, unemployment rate, the dollar, the euro, with import growth of credit risk in the banking system in Iran. They concluded that the credit risk in the banking system in Iran under the impact of variables was not significant.

Khodaei Valahzaghard et al. (2012), in another survey, presented an empirical study to measure the impacts of different factors on operating loss in one of major Iranian banks called Bank Mellat. They used a standard questionnaire and distributed it among 57 people who are mainly in top management levels. The questions were categorized into five groups including events associated with the processes and methods, events outside the organization, related events within the organization and business disruptions and system failure. The results confirmed that the loss associated with events associated with the processes and methods increased operating risk significantly, the loss associated with business disruptions and system failure increases operating risk meaningfully and the loss associated with related events within the organization increased operating risk meaningfully. The reported did not confirm that the loss associated with events outside the organization could increase operating, risk substantially. They concluded that there was not enough evidence to think that the impacts of business disruption and internal affairs are substantially different from the other event.

Lahmiri (2012) used a clustering approach to investigate the dynamics of the NASDAQ topology in times of crisis. He studied the dynamics of the NASDAQ topology before, during, and after 2008 financial crisis. First, multi resolution analysis by virtue of wavelet transform was used to denoise each NASDAQ sector return series. Second, the correlation matrix of sectors was constructed and investigated in each period to view comovements of sectors. Third, hierarchical clustering trees were built in each period to determine how the structure of the NASDAQ market evolved through time. The results suggested that interrelationships between sectors were stronger in times of crisis and especially in post-crisis period. Besides, some markets were likely to form the same cluster in all time periods; for instance the Industrial and Bank sectors and the Telecommunication and Computer sectors. Nevertheless, the general topology of the NASDAQ market had been considerably changed over periods. He concluded that the complex structure of the NASDAQ market was dynamic and was more integrated after 2008 financial crisis. His result also indicated that there were less diversification opportunities in the post-crisis period in comparison with pre-crisis period. These empirical findings were important for the development of subsequent portfolio strategies.

\section{The proposed study}

The proposed study of this paper uses regression analysis to study the relationship between banking deposit with five other independent variables including rate of banking deposit, rate of return of banking industry, money market return, commodity market and foreign exchange rates. Therefore, there are five hypotheses associated with the proposed study of this paper.

1. There is a meaningful relationship between banking deposit with money market.

2. There is a meaningful relationship between banking deposit with commodity market. 
3. There is a meaningful relationship between banking deposit with US exchange rate.

4. There is a meaningful relationship between banking deposit with Euro exchange rate.

5. There is a meaningful relationship between banking deposit and industry return.

Let RDeposit $i, t$ be the rate of banking deposit, BankR $i, t$ be the rate of return of banking industry, MarR $i$, $t$ be the money market return, ComR $i, t$ be the rate of commodity (oil), DExchR $i, t$ be the exchange rate of US currency and finally EuExchRi,t be the rate of Euro currency into domestic currency. Therefore, we have,

$$
\operatorname{RDeposit}_{i, t}=\beta_{0}+\beta_{1} \operatorname{MarR}_{i, t}+\beta_{2} \operatorname{ComR}_{i, t}+\beta_{3} \operatorname{ExchR}_{i, t}+\beta_{4} \operatorname{EuExchR}_{i, t}+\beta_{5} \operatorname{BankR}_{i, t}+\varepsilon_{i, t}
$$

We first consider the relationship among different independent variables using Pearson correlation test (Dietrich, 1991) reported in Table 1.

\section{Table 1}

Correlation ratios among different independent variables (Window: 2010-2012)

\begin{tabular}{ccccccc}
\hline Variable & BankR & ComR(Oil) & DExchR & EuExchR & MarR & RDeposit \\
\hline BankR & 1 & & & & \\
\hline ComR(Oil) & 0.021208 & 1 & & & & \\
Sig & 0.9164 & & & & \\
\hline DExchR & -0.194280 & 0.311577 & 1 & & & \\
Sig & 0.3315 & 0.1136 & & & \\
\hline EuExchR & -0.105294 & 0.233467 & 0.880442 & 1 & & \\
Sig & 0.6012 & 0.2412 & 0.0000 & & & \\
\hline MarR & 0.805954 & 0.021545 & 0.7281 & 0.043764 & & \\
Sig & 0.0000 & 0.9151 & -0.062820 & 0.8284 & & \\
\hline RDeposit & 0.169891 & 0.224493 & -0.062820 & -0.061102 & 0.218534 & 1 \\
Sig & 0.3969 & 0.2603 & 0.7556 & 0.7621 & 0.2735 & \\
\hline
\end{tabular}

Based on the results of Table 1, there is a positive relationship between commodity market growth and dependent variables including banking growth, US dollar to Rial exchange to Rials growth, Euro to dollar growth, market growth and bank deposit growth. However, there relationship is not statistically meaningful when the level of significance is five percent. The results also indicate that there is a positive between market return and US dollar exchange, commodity market growth (oil market) and bank deposit's growth rate. In terms of statistics, there is a meaningful relationship between market return with banking industry growth rate when the level of significance is five percent.

The other observation is that US dollar maintains a reverse relationship with banking rate and a positive relationship with commodity rate but they are not statistically meaningful when the level of significance is five percent. In terms of Euro exchange rate, we see a meaningful relationship only with US dollar exchange when the level of significance is five percent. In terms of the relationship between market rate and banking industry, we see a positive and meaningful relationship between these two variables but there is no other relationship observed. 


\section{The results}

The first step to perform the regression analysis is to find out whether all variables are normally distributed. We use Jarque- bera test (Bera \& Jarque, 1980, 1981) to verify the relationship and Table 2 shows details of our findings,

\section{Table 2}

The results of Jarque- bera test (Number of observations $=27$ )

\begin{tabular}{llllllc}
\hline Variables & BANKR & COMR & DEXCHR & EUEXCHR & MARR & RDEPOSIT \\
\hline j-b & 1.006388 & 0.532561 & 4.933584 & 4.358219 & 2.444606 & 7.564480 \\
Sig. & 0.604597 & 0.766224 & 0.084857 & 0.113142 & 0.294551 & 0.022772 \\
\hline
\end{tabular}

As we can observe from the results of Table 2, except one variable, bank rate deposit, all other variables are normally distributed. Fig. 1 shows details of our normality test.

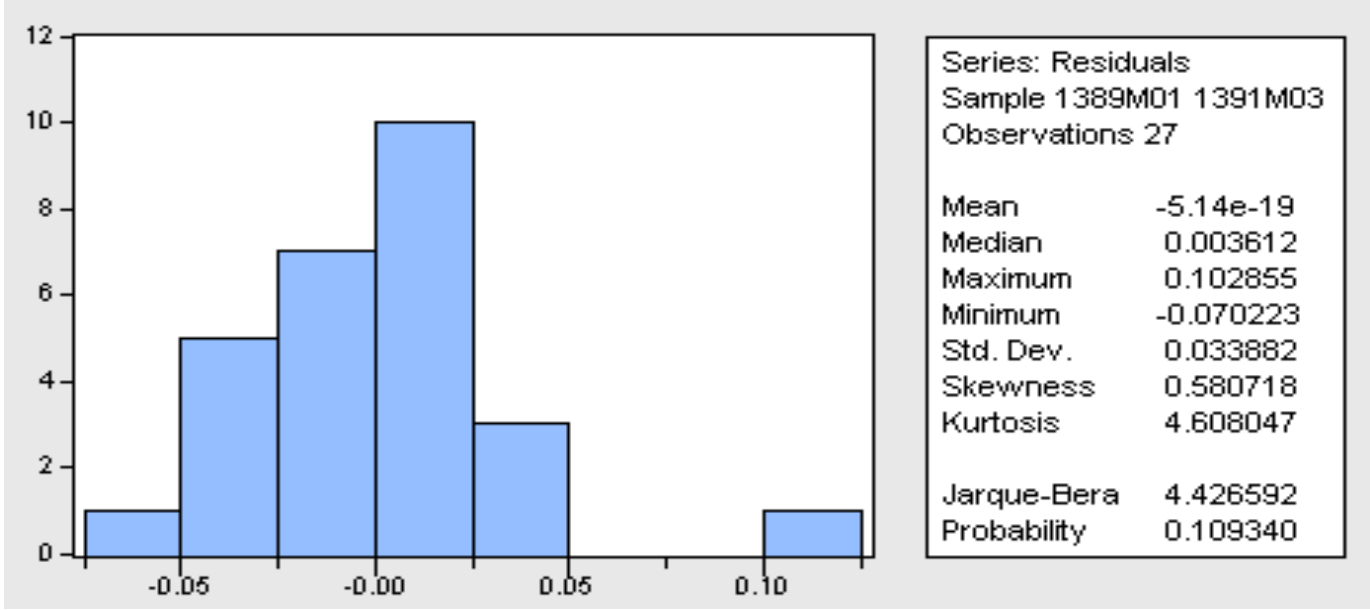

Fig. 1. The results of normality test

Table 3

The results of regression analysis using ordinary least square

\begin{tabular}{|c|c|c|c|c|c|c|}
\hline Parameter & Description & Variable & B & S.D & $\mathrm{t}$ & Sig \\
\hline$\beta_{0}$ & Constant & $\mathrm{C}$ & 0.009874 & 0.004045 & 2.440714 & 0.0246 \\
\hline$\beta_{1}$ & $\begin{array}{l}\text { Commodity growth } \\
\text { rate }\end{array}$ & $\operatorname{COMR}(-1)$ & -0.001995 & 0.000891 & -2.240236 & 0.0372 \\
\hline$\beta_{2}$ & $\begin{array}{l}\text { US dollar exchange } \\
\text { rate growth }\end{array}$ & DEXCHR(-1) & -0.004167 & 0.002272 & -1.833874 & 0.0824 \\
\hline$\beta_{3}$ & $\begin{array}{l}\text { Euro exchange rate } \\
\text { growth }\end{array}$ & EUEXCHR(-1) & 0.005676 & 0.002388 & 2.376920 & 0.0281 \\
\hline$\beta_{4}$ & Bank growth rate & BANKR(-1) & -0.278826 & 0.161053 & -1.731267 & 0.0996 \\
\hline$\beta_{5}$ & Market return & MARR(-1) & 0.321085 & 0.169996 & 1.888782 & 0.0743 \\
\hline$\beta_{6}$ & Moving average & $\operatorname{MA}(1)$ & -0.940418 & 0.065571 & -14.34208 & 0.0000 \\
\hline
\end{tabular}

$\mathrm{R}^{2}=0.55, \mathrm{AdR}^{2}=0.41, \mathrm{~F}=3.97, \mathrm{D} . \mathrm{W}=1.81$, S.E.of regression $=0.028$, Sum squared resid $=0.014$ 
As we can observe from the results of Table 3, all t-student values are statistically meaningful when the level of significance is ten percent and some of the parameters are even meaningful when the level of significance is five percent. In addition, F-value (Fisher, 1915) indicates that there is a linear relationship between dependent variable and independent variables. Durbin-Watson is also within acceptable limit, which means there is no autocorrelation between residuals. The results also indicate that the rate of bank deposit is negatively associated with commodity growth rate (-.001995), US dollar exchange rate (-0.004167), bank growth rate (-0.278826) and moving average (-0.940418). In addition, dependent variable is positively associated with Euro exchange growth rate $(0.005676)$.

\section{Conclusion}

In this paper, we have presented an empirical study to determine the relationship between banking deposit and other important factors such as capital market, money market, commodity market, foreign exchange rates such as US dollar and Euro exchange rates to local currency (Rials). The proposed study of this paper has gathered the necessary data over the period of 2010-2012 and using ordinary least square technique studied various hypotheses. All t-student values were statistically meaningful when the level of significance was ten percent and some of the parameters were even meaningful when the level of significance was five percent. The results indicated that the rate of bank deposit was negatively associated with commodity market growth rate (-.001995), US dollar exchange rate ($0.004167)$, banking industry growth rate $(-0.278826)$ and moving average $(-0.940418)$. In addition, dependent variable was positively associated with Euro exchange growth rate (0.005676).

\section{Acknowledgment}

The paper was financially supported by Islamic Azad University and the authors would like to acknowledge them. We are also grateful for constructive comments on earlier version of this paper, which has significantly contributed to quality of this paper.

\section{References}

Bera, A.K., \& Jarque, C.M. (1980). Efficient tests for normality, homoscedasticity and serial independence of regression residuals. Economics Letters, 6(3), 255-259.

Bera, A.K., \& Jarque, C.M. (1981). Efficient tests for normality, homoscedasticity and serial independence of regression residuals: Monte Carlo evidence. Economics Letters, 7(4), 313-318.

Beikzad, J., \& Ghorbannejad Maleki, S. (2012). Effective factors on bank resource mobilization. Management Science Letters, 2(3), 763-768.

Dietrich, C.F. (1991) Uncertainty, Calibration and Probability: The Statistics of Scientific and Industrial Measurement, $2^{\text {nd }}$ Ed., A. Higler. ISBN 9780750300605

Fisher, R.A. (1915). Frequency distribution of the values of the correlation coefficient in samples from an indefinitely large population. Biometrika 10(4), 507-521.

Karami, M., Mehdiabadi, A., Shahabi, A., \& Mardani, M. (2012). An empirical study for measuring the success index of banking industry. Management Science Letters, 2(4), 1155-1166.

Khodaei Valahzaghard, M., Kashefi, M., Alikhani, A. \& Hosseini, S.E. (2012). A survey on important factors influencing brand equity: A case study of banking industry. Management Science Letters, 2(5), 1747-1754. 
Khodaei Valahzaghard, M., Khalili Araghi, M., Golampour Papkiyadeh, S.M., \& Khodaei Valahzaghard, S. (2012). An empirical study to measure the effects of various factors on operating loss. Management Science Letters, 2(6), 1895-1900.

Lahmiri, S. (2012). A clustering approach to examine the dynamics of the NASDAQ topology in times of crisis. Management Science Letters, 2(6), 2113-2118 